\title{
Khorsabad/Dūr-Šarrukin Kazısı ve Asar-ı Atika Nizamnamelerine Etkisi
}

\section{The Khorsabad/Dūr-Šarrukin Excavation and Its Impact on the Asar-ı Atika Nizamname's}

\author{
Bülent Genç ${ }^{1}$ (D)
}

1Mardin Artuklu Üniversitesi, Edebiyat Fakültesi, Arkeoloji Bölümü, Mardin, Türkiye

\section{ORCID ID: B.G. 0000-0001-9328-1339}

\section{Sorumlu yazar/Corresponding author:} Bülent Genç

Mardin Artuklu Üniversitesi, Edebiyat Fakültesi, Arkeoloji Bölümü, Mardin, Türkiye

E-posta: bulendgenc@hotmail.com

\section{Başvuru/Submitted: 27.03.2021}

Revizyon Talebi/Revision Requested: 02.06.202 Son Revizyon/Last Revision Received: 30.10 .2021 Kabul/Accepted: 30.10 .2021

Atıf/Citation: Genc, B. (2021). Khorsabad/DürŠarrukin kazısı ve asar-ı atika nizamnamelerine etkisi. Anadolu Araştırmaları-Anatolian Research, 25, 117-139.

https://doi.org/10.26650/anar.2021.904234
Bir şehrin kütüphanelerinden sessizce taştığımız Y. Sezer'in anisina...

\section{Öz}

Musul'a Fransa konsolosu olarak atanan Paolo Emilio Botta ile 19. yüzyılın son çeyreğinde Mezopotamya Arkeolojisi'nde önemli değişimler yaşanmaya başlar. Botta'nın Musul çevresinde yaptığı araştırmalar sırasında Khorsabad köyünden gelen bir kişi, bir tepenin üzerine inşa edilmiş kabartmalarla bezeli taşlar ve yazıtlardan bahseder. Kuyunjik'teki üç ay süren yorucu çalışmalardan sonra Botta, 20 Mart 1843'te bir grup iş̧̧isini Khorsabad'a göndererek kazıya başlatır. Ancak Botta'nın Musul'daki çalışmalarında bir süre sonra bazı problemler baş göstermeye başlar. Özellikle vilayetteki Mehmed Paşa'nın çeşitli engeller oluşturduğu görülmektedir. Bu bağlamda Botta'nın kazı izin ve belgelerini, Musul Paşası'nın engellerini ve Botta'nın Khorsabad'ta yaşadığı hikâyenin ayrıntılarını, arka planını ve konu ile ilgili yazışmalarını öğrenmek için Osmanlı Arşivi'nde araştırmalarda bulunduk. Botta'nın Khorsabad'da yaşadığı problemler, kazı iznine ve kazı evi inşasına dair şartlar, Botta'nın bahsettiği ve köy evlerinin yanında bir kale gibi çizilerek İstanbul'a gönderilen kazı evinin planı ve köylülerin Botta'nın çalışmalarına ve kazı evine karşı sunduğu dilekçeler gibi belgelerle karşılaştık. Bu makalede söz konusu belgeler üzerinden Botta'nın kazı dönemlerini, izin belgelerini ve karşılaştığı problemleri yeniden okumaya çalışarak bu dönemin nasıl ele alındığını ve nasıl değerlendirildiğini anlamaya çalıştık. Özellikle Khorsabad bağlamında Botta'ya verilen kazı iznini ve maddelerini gözden geçirerek sonraki Asar-ı Atika Nizamnameleri'ne katkısını irdeledik.

Anahtar Kelimeler: Khorsabad, Paolo Emilio Botta, Musul, Kuyunjik, Assur, Asar-I Atika Nizamnameleri

\section{ABSTRACT}

When Paolo Emilio Botta was appointed to Mosul as the French consul in the last quarter of the 19th century, significant developments in Mesopotamian archeology occurred. During Botta's studies in the Mosul area, a resident of the village of Khorsabad mentioned reliefs and inscriptions on top of a hill. Botta dispatched a group of workmen to Khorsabad on March 20, 1843, after three months of arduous work in Kuyunjik. However, problems began to arise shortly after his work in Mosul. Particularly Mehmed Pasha in the province creates various obstacles. In this 


\begin{abstract}
context, we searched the Ottoman Archives to learn more about Botta's excavation permits and documents, the obstacles created by the Pasha of Mosul, and the details, background, and correspondence of Botta's story in Khorsabad. We came across many documents, which included details as to the problems Botta experienced in Khorsabad, the conditions about the excavation permit and the construction of the excavation house, the plan of the excavation house mentioned by Botta, which was shown to be like a castle next to the village houses and sent to Istanbul, and the petitions of the villagers against Botta's research and the excavation house. In this article, we tried to understand how this period was understood and handled by re-reading Botta's excavation periods, permit documents, and the problems he encountered through the available documents. In particular, in the context of Khorsabad, we reviewed the excavation permission and articles given to Botta and examined its contribution to the Asar-ı Atika Regulations.

Keywords: Khorsabad, Paolo Emilio Botta, Mosul, Kuyunjik, Assur, Asar-I Atika Nizamname's
\end{abstract}

\title{
EXTENDED ABSTRACT
}

The documents related to Botta's excavation in Khorsabad, the excavation house he built, and the excavation permit reveal in detail the difficulties Botta faced from the beginning of the excavation. Although it is stated that Botta did not have an excavation permit, the reports, and letters that we have discussed in detail in this study and the agreement signed between the two countries regarding the duration, place, and conditions of the excavation (Fig. 3) reveal that Botta did, in fact, have permission. Likewise, the villagers state in their petitions that Botta asked permission to dig the hill near the village and got permission from the Pasha. Botta resumed his investigation with the rights granted by Mosul Governor Mehmed Pasha, and on April 20, 1843, he asked permission for the excavation house to be built in Khorsabad. In the necessary papers, he declares that following the excavation, he will restore the houses he purchased on August 21, 1843, to their owners, with the evidence of the villagers whose names are included in the petition.

However, shortly after the start of the excavation and completion of the excavation house, the villagers began to complain. The people of Khorsabad, in their petitions, mention Botta's excavations and state that the courtyard in the excavation house was over 64 meters, and the rooms were fortified and very stable. On the grounds that the excavation had caused damage, the villagers request that an investigation be undertaken in the region. An inquiry team is dispatched, and the kad's reports and the home plan are drafted. On the other hand, Botta wrote a letter to the French Ambassador Baron de Bourqueney on October 14, 1843, listing his problems, and the troubles encountered. He writes in detail about the difficulties caused by the Pasha trying to portray the excavation house like a castle and gives the dimensions of the house (approximately $21 \times 15 \mathrm{~m}$ ). The height of the walls is close to 2 meters. In the reports dated October 19, 1843, and October 23, 1843, it is mentioned that the consul had started a very large construction, a large building similar to a mansion and that the building had a large $i w a n$, three rooms, a large courtyard, and about 40 loopholes on all four sides. This building is also said to have harmed the foundations of some surrounding homes. The officer dispatched to investigate the region reports that the structure was constructed exactly as the people described it, along with a detailed layout of the excavated areas, village dwellings, and 
excavation house (Fig. 2). In this plan, which we found in the Ottoman Archives, these details were listed. According to this plan, there were about forty arrow slits on the outer walls of the house, which consists of three rooms, a toilet, and a courtyard. The doors and windows of the rooms and the entrance of the courtyard were indicated. In particular, the drawing of the arrow slits seems to reinforce the perception that this was a structure built for defense purposes. Emphasizing that the courtyard was over 64 meters serves a similar purpose. In addition, the schematic plan of some houses in Khorsabad and the areas excavated by Botta are engraved on this plan (Fig. 2). The earliest excavation house in Mesopotamia and the archaeological literature was this plan, which was drawn like a castle or defense construction. This definition is confirmed by Botta's remark that he created this house to protect the relics from numerous threats throughout the process of assembling and shipping ancient objects.

In a report dated November 01, 1843, France requested permission from the Ottoman Government for Botta to excavate in Khorsabad. The letter aims to intimidate the Ministry of Foreign Affairs by mentioning that there could be bigger problems if the obstacles imposed by the governor of Mosul were to be heard in European capitals such as Paris, London, and Petersburg. Thereupon, the Ottoman Empire began to try and solve this issue. It was considered inappropriate for the governor of Mosul to first give permission and then create obstacles. The excavation circumstances and the situation of the excavation house, which sparked a diplomatic crisis between the two countries, were examined, and Botta was granted the necessary license. The governor's appointment of an official to be paid out of his own pocket, as well as the fact that the excavation and research of another location, as well as the extension of the time limit, would not be permitted, despite the discovery of paintings and antiques in the location where the excavation began, were emphasized. Through the agreement between the Ottoman Empire and France, the excavation period and conditions were determined, and this crisis was solved. It can be thought that this excavation permit, which consists of six articles related to Khorsabad, was also a source of inspiration for the Asar-1 Atika Nizamname's, which were put into effect in 1869, 1874, and 1884.

After this problem was resolved through a special agreement thanks to the efforts of the French Ambassador Baron de Bourqueney, Botta continued his work from where he left off. Flandin, on the other hand, was significantly delayed and did not reach Mosul until approximately May 4, 1844. Botta's controversial excavation house was permitted to remain until the project was completed. With the 1 -year permit that Flandin had with him, excavations were resumed right away. From mid-May 1844 to the end of October 1844, Botta worked for around six months with three hundred employees. In August, Botta wrote to Layard talking about their success and Flandin's skills. Flandin and Botta worked well together. As the reliefs emerged, Flandin painstakingly sketched and planned the structures. Through the relatively large group of workers and hastily continued excavations, Flandin and Botta revealed a large 
part, if not all, of the palace. The outer city was hardly touched. Botta excavated the northern part of the structures, along with 14 great halls and some exterior facades.

Botta ended his excavations at Khorsabad in October 1844. Khorsabad was situated at a distance from the rivers suitable for shipping, so very heavy and large stone blocks had to be transported to Mosul, $25 \mathrm{~km}$ away. The transportation of Assyrian reliefs and sculptures to France was extremely challenging. These massive relics, which were carried by peasants and piled onto rafts, had to cross the Tigris River to reach the Persian Gulf, where they were shipped to France. Botta used the same modes of transportation as Assyrian architects. He had large wagons built to transport the reliefs to Mosul. Mehmed Pasha provided oxen to pull wagons, but he immediately took them back. Since this transport was carried out during the rainy season, the wheels kept sinking into the mud. Therefore, he had to leave one of these oxen on the road between Khorsabad and Mosul. It took until June 1845 to move all the artifacts to the riverside. After the wagons arrived in Mosul, the statues were loaded onto large rafts/kelek formed with hundreds of inflated hides, and set off for Baghdad and then the Persian Gulf. The artifacts were loaded on a French ship from Basra and were set out to be sent to Paris after reaching Le Havre. The items arrived in Paris in February 1847. On May 1, 1847, four years after Botta began excavations in Khorsabad, the Louvre opened its collection of the first Assyrian artifacts to the public. He and Flandin published the excavations of Khorsabad and its descriptions in 1849 and 1850 under the title "Monument de Nineveh," believing the settlement he uncovered was Nineveh. 


\section{Giriş}

II. Sargon'un (MÖ 721-705) başkenti olan Khorsabad/Dūr-Šarrukin, Ninive'nin 24 km kuzeyinde, Dicle'nin bir kolu olan Khosr Nehri üzerinde ve daha önce yerleşilmemiş olan bir bölgede kurulmuştur. Bu yeni yerleşime Khorsabad/Dūr-Šarrukin (Loud, Frankfort et al. 1936, s.129; Fuchs, 1994, s. 309, 372), yani "Sargon'un Kalesi” adı verilmiştir, ancak günümüzde yakınındaki köy vesilesi ile genellikle Khorsabad olarak bilinmektedir. Yaklaşık 300 hektarlık bir alanı kaplayan bu kentin sitadeli 25 hektardan oluşmaktadır ve yerleşim kare biçimli bir görünüm arz etmektedir ${ }^{1}$ (Fig. 1). II. Sargon'un krallığı süresince kullanılmış olan bu kent, kralın MÖ 705 yılında bir savaşta öldürülmesinden sonra kullanılmamış veya terk edilmiştir ${ }^{2}$. Bu bağlamda Khorsabad/Dūr-Šarrukin, kent planı ve mimari yapılarıyla ilgili oldukça önemli bilgiler sunmaktadır. Kentin sadece II. Sargon döneminde kullanılmış olması, kendi dönemi içindeki Assur kent planlaması, mimari yapıları ve çeşitli bulgular ile ilgili veriler taşıması bakımından önemlidir. Bu anlamda Khorsabad'ın keşfine, bu alanla ilgili ilk verilere, kazı ve araştırma süreçlerine odaklanarak 19. yüzyılın ortalarından itibaren ilk kazı çalışmalarına ve bu çalışmaları düzenleyen ilk kazı izinlerine değineceğiz ${ }^{3}$. Böylece Mezopotamya'daki en erken kazı çalışmasını, çalışma sırasında yaşanan problemleri ve çözümlerini irdeleyerek bu sürecin kazı izinlerine nasıl dönüştüğünü anlamaya çalışacağız.

Bilindiği gibi 18. yüzyılın ortalarından itibaren Mezopotamya batılı gezgin, seyyah, diplomat ve araştırmacı gibi çeşitli alanlardan insanların uğrak yeri olmaya başlar. 19. yüzyıl boyunca devam eden bu ilgi yüzyılın ortalarından itibaren ise birtakım kazı çalışmalarına ve Avrupa'daki çeşitli müzeler için eser transferine dönüşür. Bu dönemde Mezopotamya'daki arkeolojik alanlarla ilgilenen söz konusu diplomat ve araştırmacilardan birisi de Paolo Emilio Botta'dır. Uzunca bir dönem boyunca hayatını bir doğa bilimci olarak sürdüren

1 Yerleşimin taş temel üzerine kerpiçlerden oluşan sağlam ve dayanıklı duvarları 23 m. kalınlığındadır. Bastionlar 11.5-13 metre uzunluğunda 5.5 metre ölçülerinde, 14-19 metrelik aralıklarla tasarlanmışlardır. Kulelerle çevrelenmiş sur duvarları yaklaşık olarak $7 \mathrm{~km}$. uzunluğunda olup yüksekliğinin 12 metreye kadar ulaşabildiği belirtilmektedir (Loud - Altman, 1938, s. 18). Kente girişi sağlayan yedi kapı asimetrik olarak yerleştirilmiştir ve bunlardan üçü kabartmalarla bezelidir. Nimrud/Kalhu ve Ninive'de olduğu gibi asıl kentten ayrı iki bölüm halinde ve güneyde imparatorluğun silah deposu, kuzeybatıda ise krali saray ve sitadel ayrı duvarlarla korunmaktadır (Bunnens, 1996, s. 173; Gates, 2011, s. 173). Sitadel alanı aşağı kentten kalınlığg 7.5 metreye varan bir duvarla ayrılmaktadır. Aşağı kentten sitadele iki kapıyla ulaşılmaktadır.

2 II. Sargon'un savaş alanında öldürülmesiyle yayılma politikası tamamlanamamıştır. Kralın son seferinin Tabal'a karşı olduğu önerilmektedir ve genellikle düşmanının Kimmerler olduğuna inanılmaktadır. II. Sargon'un savaşta öldürülmesiyle krali kampı ele geçirilerek yağmalanmıştır. Sanherib, babasının düşman ülkelerinde öldürüldüğünü ve cesedinin defnedilemediğini özellikle belirtmektedir (Livingstone, 1989, s. 7779; Tadmor, 1989, s. 11). Savaş alanında öldürülmesi veya cesedinin düşman ellerine geçmesinden dolayı gömülemediği düşünülmektedir. Kralın kendi sarayına veya kentine gömülmesi Assur kralları için önemli bir gelenektir. II. Sargon Assur İmparatorluğu'nda savaşta öldürülen ilk ve tek kraldır ve bu nedenle uygun biçimde gömüsü yapılamamıştır. Kralın bu şekilde öldürülerek kendi yurduna gömülememesine II. Sargon’un günahının neden olduğuna inanılmaktadır. Sanherib'in Khorsabad/Dūr-Šarrukin'i bu nedenle terk etmiş olabileceği tartışılmaktadır (Tadmor, 1989, s. 28-29).

3 Bu konuda ayrıntılı bir çalışma için ayrıca bakınız (Genç, 2019, s. 145-171). 
Botta arkadaşlarının aracılığıyla Fransa Konsolosluğu'nda çalışmaya başlar ve 1842 yılında Musul'a konsolos olarak gönderilir ${ }^{4}$. Botta'nın Musul'a gönderilmesiyle Assur arkeolojisinde bir dönüm noktası olarak ele alacağımız kazı çalışmalarının başlandığı anlaşılmaktadır. Ancak Botta, Musul'a hareket etmeden önce bir aile dostu ve oryantalist olan Jules Mohl tarafından Assur İmparatorluğu'nun kalıntılarını temsil ettiğine inanılan Dicle Nehri'nin her iki yakasındaki devasa höyükleri keşfetmesi için cesaretlendirilerek yönlendirilir ve teşvik

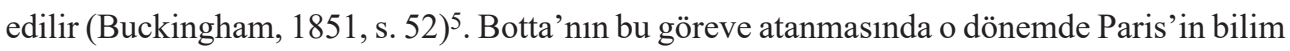
çevrelerinde dikkate değer bir etkisi olan Mohl'un ${ }^{6}$ etkili olduğu belirtilmektedir (Larsen, 1996, s. 21). Mohl'un Botta'yı seçmesinde onun Arap ülkelerindeki deneyimi, Arapçayı akıcı bir şekilde konuşması etkili olmuştur. Botta, görevinin Mohl tarafından belirlendiğini defalarca ifade etmektedir (Larsen, 1996, s. 22). Bu vesile ile Musul'a gönderilen Botta oraya vardıktan sonra aylarca Musul ve çevresindeki alan ile Qoyunjuk/Kuyunjik ve Nebi Yunus höyüklerinde bir takım incelemelerde bulunmuştur. Botta'nın Mohl'a gönderdiği mektup ve çizimler söz konusu keşifleri anlatmaktadır. Hatta Khorsabad’ta keşfettiği ilk Assur sarayı ile ilgili ayrıntıları Mohl'a ve Layard'a yazdığı mektuplarda açıklamaktadır (Mohl 1845; Larsen 1996, s. 24). Mohl, Botta'nın raporlarını akademiye sunmuş ve bu çalışmalar Fransa'nın dikkatini ve ilgisini çekmiştir (McGovern ve McGovern, 1986, s. 112). Musul civarı ile Kuyunjik ve Nebi Yunus’ta yaptığı araştırmalardan sonra Botta, öncelikli olarak birkaç

4 Botta'nın Musul'a konsolos olarak gönderilmesiyle ilgili üç farklı tarih önerilmektedir. Botta'nın Musul'a 1840 (McGovern ve McGovern, 1986, s. 111), 1841 (Larsen, 1996, s. 96) ve 1842 yıllarında gönderildiği belirtilmektedir (Buckingham, 1851, s. 52; Hilprecht, 1903, s.73).

5 Ayrıca Carsten Niebuhr'un Musul'a ziyaretini ve bu yolculuğunu anlatan içinde bir Musul haritasının da yer aldığı kitabını (Niebuhr, 1778, s. 334-370) Botta'nın okuduğu Larsen tarafından belirtilmektedir. Nehrin karşısındaki alanı Ninive olarak adlandıran Niebuhr, iki büyük höyükten bahseder ve güneyde yer alan küçüğünün Nunia adını taşıdığını daha büyük olan ve kuzeydekinin ise Kalla Nunia adını taşıdığını belirtmektedir. Bu höyüğün üzerinde "Koindsjug" adında bir köyün bulunduğuna değinen Niebuhr höyükle birlikte bu adın arkeoloji literatürüne "Kuyunjik" olarak geçtiğini vurgulamaktadır (Niebuhr, 1778, s. 368, Tab. XLVI; Larsen, 1996, s. 7-8). Niebuhr'un çizimi ve haritasından sonra gerçek bir çalışma Claudius James Rich ile başlamıştır (Rich, 1836, s. 29-65). Rich 1820 yılında Ninive'nin dikkatli bir ölçümünü yaparak doğru haritasını çizmiştir. Ancak Rich'in çalışmaları ölümünden sonra 1836 yılında yayınlanmıştır. Bu haritada Kuyunjik ve Nebi Yunus olarak adlandırılan höyükler yer almaktadır ve Rich bu höyüklerde çeşitli incelemelerde bulunmuştur. Bu alanlarda toprak altındaki duvar temellerinden bahseden Rich, yerel insanların kendisine birkaç yıl önce, üzerinde insan ve hayvan kabartmalarının yer aldığı iki insan yüksekliğinde gri bir taştan bahsettiğini aktarmaktadır. Bu alabasterlerin üzerinde çivi yazılarının da bulunduğu belirtilmektedir (Rich, 1836, s. 30-39; Larsen, 1996, s. 9).

6 Claudius James Rich'in Assur yıkıntıları ile ilgili yayınlarını okuduktan sonra Mohl'un Ninive'ye ilgisinin arttığı bu vesile ile Rich'in Mezopotamya'dan getirerek British Müzesi'nde sergilediği buluntuları ziyaret ettiği belirtilmektedir. Bunlardan etkilenen Mohl, Yakındoğu'nun büyük uygarlıklarının keşfinde Fransa'nın bulunma olasılığını da göz önüne almıştır (Larsen, 1996, s. 21). Rich, Bağdat’ta kaldığ 1 yıllar boyunca ülkenin tamamındaki höyükleri ve yıkıntıları ziyaret ederek ölçümler-planlar yapmış ve buluntular toplamıştır (Rich, 1836, s. 29-65). Küçük bir koleksiyon halinde bir araya getirdiği bu eserler ölümünden sonra eşi tarafından British Müzesi'ne satılmıştır. Burada sergilenen eserler Assur ve Babil'deki eski kültürlerin somut kanıtlarını oluşturması açısından son derece önemlidir. Austen Henry Layard'ın da müzede söz konusu koleksiyonu gördüğü belirtilmektedir. Botta'nın Musul'a Ninive'de kazı yapması amacıyla gönderilmesi için Fransız otoriteleri tarafından alınan kararda Rich'in kitabının yayınlanmasının rol oynadığı vurgulanmaktadır (Larsen, 1996, s. 9). 
işçiyi kısmen üzerinde bir köyün yer aldığı Nebi Yunus'ta7 eski taş temelleri araştırması için çalıştırmaya başladı. Fakat Yunus peygamberin mezarıyla caminin yıkılacağından veya zarar göreceğinden korkan Mehmed $\mathrm{Paşa}^{8}$ ve yerel dini liderlerin şiddetli muhalefeti nedeniyle bu çalışmadan vazgeçmek zorunda kaldı. Botta, Nebi Yunus’ta yaşadığı zorluklardan sonra Aralık 1842 yılında bir grup işçiyle Kuyunjik’te çalışmaya başlamıştır (Buckingham, 1851, s. 54-56; Hilprecht, 1903, s. 74; Larsen, 1996, s. 11-12).

Botta'nın işçileri Kuyunjik’ta çalışmaya başladıklarında Musul'a 25 km. uzaklıktaki Khorsabad $^{9}$ köyünden ziyarete gelen biri bir tepenin üzerine inşa edilmiş kabartmalarla bezeli taşlar ve yazıtlardan bahseder. Başlangıçta bu hikâyeyi ciddiye almayan Botta, Kuyunjik'teki üç ay süren zahmetli ve sonuçsuz çalışmalardan sonra yaklaşık 20 Mart 1843'te yılmış bir şekilde bu hikâyenin arkasındaki gerçeği merak eder ve bir grup işçisini ${ }^{10}$ Khorsabad'a göndererek kazıya başlatır (Botta ve Flandin, 1850, s. 5; Bonomi, 1857, s. 12). Kazının başlamasından üç gün sonra kabartmalar ve yazıtlar bulunduğunun haberini alır. Yüzeysel bir çalışmayla çok sayıda Assur kabartmaları ve çeşitli parçalar bu alandan ele geçirilir (McGovern ve McGovern, 1986, s. 110-111; Larsen, 1996, s. 14-20). Botta hala kuşkuludur ve bu yazıtlardan birinin çizimini yapması için bir adamını oraya gönderir. Sonuçta durumun gerçek olduğunu anlayınca çalışmalarını Khorsabad'ta sürdürmeye karar verir ${ }^{11}$. 5 Nisan 1843 'te (Mohl, 1843, s. 61-72) Paris'e gönderdiği mektubunda ortaya çıkardı̆̆ 1 buluntulardan bahsetmektedir (Buckingham, 1851, s. 56-57; Hilprecht, 1903, s. 75-76; Larsen, 1996, s. 13). 2 Mayıs 1843 'te Mohl'a gönderdiği mektubun daha önemli olduğuna değinmektedir ve yazıtların kopyalarını da bu mektuba eklemiştir (Botta ve Flandin, 1850, s. 5).

Botta'nın Musul'daki çalışmalarında bir süre sonra bazı problemlerin başladığı anlaşılmaktadır. Özellikle vilayetteki Mehmed Paşa'nın çeşitli engeller oluşturduğu

$7 \quad$ Kuyunjik'in yaklaşık $1 \mathrm{~km}$. güneyinde yer alan ikinci tepelik Nebi Yunus olarak adlandırılır ve bu alanda ekal māšarti yer almaktadır. Nebi Yunus Tepesi’nde Yunus peygamberle ilgili olduğu düşünülen bir türbe bulunmaktadır (Rich, 1836, s. 32; Thompson, 1934, s. 95). Bu dinsel mekân buradaki ve çevresindeki kazıları kısıtlamıştır. Bununla birlikte bu yapının Assur savaş teçhizat ve donanımlarının merkezine yapıldı ğı anlaşılmıştır (Thompson, 1934, s. 95-104; Turner, 1970, s. 68, Pl. XV; Gates, 2011, s. 176).

8 Musul valisi olarak Mart 1836-Mart 1844 tarihleri arasında görev yapmış olan İncebayraktar Mehmed Paşa (?-1844) (Kuneralp, 2003, s. 99).

9 Bir köyün ismi olan Khorsabad genellikle tüm yerleşim için kullanılmaktadır fakat bu yıkıntılar ayrıca Saraoun olarak da bilinmektedir. Saraoun isminin kentin özgün adı olan Dūr-Šarrukin'i çağrıştırdığına değinilmektedir (Larsen, 1996, s. 30). Ayrıca Khorsabad için farklı isimler olarak Khirsabad, Khorstabad, Khoroustabaz, Khastabad veya Kheste abad adlarının da kullanıldığı belirtilmektedir (Botta ve Flandin, 1850, s. 18). Büyük bir bataklığın yanında yer alan Khorsabad'da sıtma nedeniyle 1843 yazında Botta'nın da hastalandığı bilinmektedir. $\mathrm{Bu}$ nedenle hastalıkların bulunduğu ve barındığ belirtilmektedir (Buckingham, 1851, s. 72; Larsen, 1996, s. 26).

10 Bu işçilerin başında Kuyunjik’teki kazıların başlangıcından bitişine kadar Botta'nın yanında olan ve en güvendiği adamlarından Naaman ibn Naouch (Nuh oğlu Numan) bulunmaktadır. Botta, Khorsabad'ı keşfetmesi için işçilerin başı olarak Naaman ibn Naouch'1 göndermiştir (Buckingham, 1851, s. 69).

11 Botta’nın Khorsabad'da altı ay içinde Assur yapılarını ortaya çıkardığı belirtilmektedir (Buckingham, 1851, s. 21). 
görülmektedir. Mehmed Paşa gerçekte Botta'nın ne aradığını merak ediyordu ve bu nedenle çıkarılan metal eserler altın olup olmadıklarının incelenmesi için paşaya götürülüyordu. Hiçbir şey çıkmayınca da Mehmed Paşa, Botta'nın kurnazlık yaptığını düşünüyordu. Böylece gizli hazineyi ortaya çıkarmaları için Botta'nın işçilerini hapse atmakla ve işkence yapmakla tehdit ediyordu (Botta ve Flandin, 1850, s. 7, Buckingham, 1851, s. 58; Hilprecht, 1903, s. 78). Bu durum Paşa'nın kazıyı durdurma emrini verdiği 5-12 Ekim 1843 yılına kadar sürdü (Botta ve Flandin, 1850, s. 9). Botta, Khorsabad'da ziyareti sırasında kalabileceği bir ev inşa etmişti. Mehmed Paşa İstanbul'a bir rapor yazarak kendi izniyle Khorsabad'da Botta tarafindan inşa edilen evin gerçekte bir kale olduğunu ve buradan bölgenin güçle bastırılabileceğini ve alınacağını vurguluyordu (Botta ve Flandin, 1850, s. 7; Hilprecht, 1903, s. 78). Görünüşe göre Paşa, Botta'nın vazifesini ve çalışma nedenini anlayamıyordu. Botta'nın Khorsabad'dan herhangi bir buluntuyu Fransa'ya göndermek şöyle dursun kazı izni dahi olmadığı belirtilmektedir (Larsen, 1996, s. 28). 15 Ekim'de Botta, İstanbul'daki büyükelçiliğe durumu açıklayan bir mektup yazd1 ${ }^{12}$. Ancak Botta büyükelçilikten gelecek sonucu beklerken Mehmed Paşa, Kadı'yı incelemelerde bulunmak için Khorsabad'a gönderdi. Bir kaleymiş gibi ölçüleri alınarak çizilen evin planı ve haritası bir rapor ile birlikte İstanbul'a gönderildi (Buckingham, 1851, s. 59; Bonomi, 1857, s. 15-16, Larsen, 1996, s. 28).

Bu konu ile ilgili olarak yaptığımız araştırmalarda Botta'nın Khorsabad'da yaşadığı problemler, kazı iznine ve kazı evi inşasına dair şartlar, bir kale gibi çizilerek İstanbul'a gönderilen kazı evinin planı ve köylülerin Botta'nın çalışmalarına ve kazı evine karşı sunduğu dilekçeler gibi önemli bazı belgelere ulaştık ${ }^{13}$. Söz konusu en erken 20 Nisan 1843 tarihli belge, Botta'nın kazı evi inşası için başvuru belgesini kapsamaktadır. Botta'nın Musul Paşası'na yazdığı ve Musul'un Fransa Konsolosu P. E. Botta biçiminde konsolosluk mührüyle damgaladığı dilekçede konuyu şöyle dile getirmektedir.

"Yüce vezir hazretlerine: Bu şukkayı (yazıyı) kaleme almamın sebebi şudur: Horsabad'ta kazı esnasında bir hastalığa yakalanmıştım. Neredeyse kış gelmek üzere. Bunun için buradaki çalışmamız bitene kadar istirahat edeceğimiz ahşaptan ve çamurdan üç dört odalık bir bina yapmayı münasib gördüm. Bu şekilde güneşin, yă̆murun ve soğuğun etkisinden kurtulabiliriz. İsimiz bittikten sonra bu ev mülk sahibine kalabilir. Tipkı daha önce burada bazı evler satın alıp sahiplerine konsolosluk mührüyle bir senet verdiğimiz gibi. Bu konsolosluk senedinde belirtildiği gibi evleri mülk olarak almadık, sadece kazı yapmak ve kadim taşları çıkarmak maksatl aldık. Kazı bittikten sonra araziler sahiplerine kalacak. Şimdi sizden bize bu hususta izin vermenizi ve bir de yapacă̆ımı binaya kimsenin müdahale etmeyeceğine dair bir tezkire ${ }^{14}$ vermenizi istirham ediyorum. Hem sizi hem de mülk sahibini bir hususta temin

12 Osmanlı Arşivi’nde ulaştığımız bu mektup 14 Ekim 1843 yılında yazılmıştır.

13 Osmanlı Arşivi'ndeki bu belgelerin transkripsiyonunu yapan Doç. Dr. Vural Genç'e teşekkür ederim.

14 İzin alındığına dair resmi vesika. 
ederim ki yapacă̆ımız bina bizim malımız olmayacak. Buradaki işimiz bittikten sonra arazi sahibine kalacak. Bu takririmi konsolosluğumuzun mührü ile sonlandırıyorum”.

Botta'nın bu dilekçesinde 25 Receb 1259/21 Ağustos 1843 tarihli bir şahitlik kaydı da bulunmaktadir.

Bu kayıda göre, Kaza Meclisi'nde hazır bulunan Hasna ez-zımmi veled-i Şamaş Abdülkerim, Fransa Devleti Konsolusu Botta'nın vekili Koma veled-i Cercis ez-zımmi ve Şarl veled-i Mişel şahit olarak bulunmaktadırlar. "Konsolos Hastaabad köyünde antik taşlar ve resimli taşlar için kazl yaptığında yă̆mur ve soğuktan korunmak için ă̆aç ve çamurdan geçici olarak üç odalık bir bina yapmak istiyor. Kazı üç ay ya da altı ay sonra bittiğinde bina kaldırllacak ve kaldırma masrafi da ona ait olacak. Arazi ise sahibine iade edilecek. Arazi mülk olarak konsolosun olmayacak, kazl evi sadece kazı bitene kadar yağmur ve soğuktan korunmak amaçlı olacak. Bahsi geçen hristiyan ve müslümanlardan oluşan şahitler ${ }^{15}$ gibi adı geçen konsolos da buna şahittir ${ }^{16 ”}$.

Ancak bir süre sonra Khorsabad'da kazılan alanlar ve inşa edilen kazı evi ile ilgili birtakım problemler çıkmaya başlar. Khorsabad köylüleri17 bir dilekçeyle bu konu ile ilgili şikayet ve problemlerini şöyle arzetmektedirler: "Köyümüz yüksek bir tepenin üstünde yer alır. Açıkçası altı ay önce Fransa Devleti’nin elçisi efendimize şöyle arz etmişti; köyün bulunduğu tepenin batı tarafinda bazı antik ve resimli taşlar var. Yüce hazretten o taşları ve resimli taşları araştırmak ve köyün hizasında bulunan tepeyi kazmak için izin ricasında bulundu. Neticede bu izni aldı. Adı geçen elçi bu bölgeye gönderildi. Bahsi geçen yerin kazısl, keşif ve diğer faaliyetler başladi. Bu kazı işinde aşırıya kaçtı. Sonra yüce hazretten çamur ile balçıktan bir bina yapmak için izin istedi. Güneş ve sicaktan korunmak amaçlı bu bina sadece üç ay için inşa edilmişti. Kazıda çalışanların da dinleneceği bir yer olacă̆ını söyledi. Kazı bittiğinde ise bahsi geçen binayı yıkacă̆ını beyan etti. Bu izni aldr. Ancak evlerimizin etrafina öyle büyük bir bina inşa etti ki ortasında 100 zir 'adan (64 metre) daha büyük kocaman yuvarlak bir avlusu vardl. Bunun içine de bir eyvan (avlu) inşa etti. Bu binanın üç tane muhkem (sağlam) odası var. Binanin batıya bakan tarafina ise saray kapılarına benzer bir kapı yaptırdı. Bu binanın birçok da penceresi vardı. Köyümüzün işleri harap olmaya yüz tuttu. Köylülerin evlerinden üç ev de bunlar arasındaydl. Bu evlerin avluları dört taraftan kazıldı ve buralar çukurlar şeklinde bırakıldı. Bu şekilde kazllar devam eder binalar ise çoğaltılırsa köyümüzü terk etmemiz gerekir. Yüce hazretten istirhamımız şudur: Bir keşif heyeti gönderin ve şer-i şerif (Şer-i Kanun/Mahkeme) tarafindan bir tahkikat yapılsın. Ĕger siz bu işe razıysanız biz işimizi Allah'a havale ediyoruz. İşin doğrusu ondan sonra ögrenilir’".

1525 Receb 1259/21 Ağustos 1843 tarihli bu kayıttaki şahitlerin isimleri şu şekildedir; Seyyid Muhammed, Molla Abdülgafur, El-hac Bekir, Seyyid İbrahim, Istefan, Eliyas? Refed.

16 İ.MSM. 68/1987, 2 Zilhicce 1259/24 Aralık 1843.

17 Şikayette bulunan Khorsabad köylüleri şu şekildedir; Hasan, Salih, Ahmed, Faris, Abdülvehab, Ali, Osman, Mustafa, Mustafa, Haydar, Abdülvehab, Ali, Muhammed, Mustafa, Halef, İbrahim, Abdullah, Ahmed, Ali, Hüseyin, İbrahim, Yunus, Cuma. 
Khorsabad köylülerinin şikayetini değerlendiren Mehmed Paşa, Musul Kadısı'na durumu şu şekilde bildirir; "gelen dilekçeden anlayacă̆ınız üzere tarafımızdan gönderilen memur ile beraber üzerinde tartışma olan mahalle kendiniz bizzat gidiniz ve bahsi geçen binaları inceleyerek ölçülerini ve tasvirini alarak tarafimıza gönderiniz18”.

Khorsabad'ta Botta'nın yürüttüğü kazı çalışmaları, inşa ettirdiği kazı evi, kazı alanındaki evlerin satın alınması ve benzeri problemlerle ilgili olarak yapılan şikâyetler üzerine Botta, 14 Ekim 1843 yılında Fransa Büyükelçisi Baron de Bourqueney’e ayrıntılı bir mektup ${ }^{19}$ yazarak yaşadığı bütün problemleri şu şekilde anlatmaktadır.

“Botta, Khorsabad köyünde başladığ kazılarla ilgili olarak karşılaştı̆̆ bazı yeni güçlüklerden bahsederek mektubuna başllyor. Bulduğu yazıtların bütün Avrupa'nın ilgisini uyandırdığını ve bu yazıtların kopyasını almak için buraya bir çizimci veya ressam gönderilmesini istiyor ${ }^{20}$.

Botta, Khorsabad'da kalıntıları ziyaret ettiğinde kalmak için iki ay önce küçük bir ev inşa etmek istediğini belirtmektedir. Bunun için Paşa'dan izin ister ancak evin bitmesine yakın Paşa çok sayıda güçlük çıkarmaya başlar. Paşa, Khorsabad sakinleri aracılığıyla çalışmaların durdurulması ve evin yıkılması için bir dilekçe yazar. Paşa aynı zamanda kadı ve kendi görevlilerinden birini denetleme yapmak ve rapor yazmak için bu köye gönderir. Bu durumların öğrenilmesiyle Botta, Paşa'ya yazar ve onun açı izniyle kazılara başlandığını ve evin inşa edildiğini ona hatırlatır. Paşa'dan devam etmek için ricada bulunur ve Paşa Istanbul'dan konuyla ilgili bir yanit alıncaya kadar bir süre ara vermeyi teklif eder. Botta Khorsabad köylülerinin şikayet dilekçesini anlaşılmaz bulmaktadır. Bu şikayetlerin, araştırmaların genişlemesi ve büyümesinden dolayı köyde ortaya çıkan aksaklıklardan ve özellikle evin boyutları konusunda saçma ve abartılı anlatımlardan oluştuğunu belirtmektedir. Paşa'nın emriyle Musul Kadısı ertesi gün evi ölçmek ve gerçekleri doğrulamak için Khorsabad'a gönderilir. Kadı döndükten sonra gerçeklerle uyumlu bir ilam yazar. Kadı'nın ilamı Paşa için uygun olmadığından Paşa dilekçede yer alan abartılı saçmalıklarla tutarlı bir yazı yazması için kadı'ya baskı yapar. Böylece kadı'nın ilamıla birlikte Paşa'nın katiplerinden biri tarafindan yazılmış bir taslak (Porte'ye) Bab-ı Ali gönderilir.

18 İ.MSM. 68/1987, 2 Zilhicce 1259/24 Aralık 1843.

19 Botta'nın Fransızca kaleme aldığı bu mektup aynı şekilde Osmanlı Türkçesi'ne çevrilmiş ve ilgili kurumlara sunulmuştur. Mektubun giriş kısmı, "20 R 1259/14 Ekim1843 tarihi ile Musul'da olan Fransa konsolosunun Fransa elçiliğine gönderdiği mektubun çevirisidir" biçimindedir. (Kâtip orijinal mektubu çevirirken tarihi 20 Ramazan 1259 yerine yanlışlık yaparak 20 Rebiülahir 1259 olarak vermiştir.) Botta'nın mektubunun çevirisi olan bu belgede diğer belgeler ile birlikte bulunmaktadır.

20 Botta ortaya çıkardıkları kabartmaların havayla temas edince nasılda hemen canlılıklarını kaybettiklerini anladı ve Fransa'dan bir çizimci talep etti. Böylece Botta, İstanbul'dan gelecek olan raporlarla birlikte yetenekli bir çizer olan Eugene Flandin'i beklemeye karar verdi. Bu arada zamanını çivi yazılı yazıtların kopyasını almakla ve kabartmaları Khorsabad'dan Musul'a taşımakla geçirdi. 
Botta Paşa'ya verdiği sözden dolayı çalışmalarını durdurur ve Bab-ı Ali'nin iznini bekleyecektir ${ }^{21}$. Khorsabad'da inşa ettiği barınă̆ın bir kale inşa etmek istermiş gibi yansıtıldı̆̆ını belirtmektedir. Bab-ı Ali'nin böyle düşünmesini sağlamak için hareket ettiklerini vurgulayarak, dilekçede evin boyutlarını arttırdıklarından bahsetmektedir. Paşa'nın yazılı açık izni ile kazılara başladı̆̆ını, ev inşa ederken izin aldı̆̆ını, köylülerin istekleri doğrultusunda köydeki bazı evlerin satın alınması gerektiğinde yine Paşa'dan yazılı olarak izin aldı̆̆ııı belirtmektedir”.

$\mathrm{Bu}$ noktada Botta bir kale gibi çizilerek şikayette bulunulan evin genel durumunu şöyle anlatmaktadır; "Ev iki veya üç odanın dışına çıkamıyordu ve toprak ve tuğla ile inşa ediliyordu. Bu koşullar harfiyen yerine getirildi ve şu anda bu sözde kalenin tam boyutlarını veriyorum. Ev üç oda, bir mutfak ve atlar için bir avludan oluşuyor ve burada amacım antik eserlerin parçalarını bir araya getirmek ve birleştirmek, nakil süresini beklerken korumak ve böylece eserler tüm tehlikelerden korunmuş olacaktır. Bu arada ev köyün bütün evlerinde olduğu gibi tamamen toprak ve tuğlayla inşa edildi, avlusuyla birlikte 70 feet uzunluğunda $(21.336 \mathrm{~m})$ ve 50 feet genişliğindedir $(15.24 \mathrm{~m})$. Duvarlar 6 feet $(1.828 \mathrm{~m})$ yüksekliğindedir. Bu huzursuzlukları durdurmanız için affinıza sığınıyorum, fakat kendimi savunmam lazım, Paşa kesinlikle herşeyi abartılı ve yanlış bir biçimde yansitmak niyetinde. Kadı tarafindan da onaylandı̆̆ gibi evin pencereleri var ve odalardan biri tuğlayla bölünmüştür. Duvarlar kil bir kaplamayla düzgün bir şekilde kaplanmıştır, avlunun duvarları ülkenin geleneklerine göre yapılmıştır, kapıda attan inmek için bir taş (binek taşı) vardır. Bütün bu zorunluluklar bu evin geçici bir kullanım için tasarlanmadı̆̆ını fakat kalıcı olduğunu gösteriyor. Köyde ortaya çıkan güçlüklere gelince köylülerin bütün bu olaylara yabancı olduklarını söyleyebilirim; şikayetler Paşa'nın emirlerine göre yapılıyor".

"Botta köylerini ovaya taşımak isteyen köylülerden sadece evlerini satın aldı̆̆ını ancak arazinin mülkiyetini almadığını belirtmektedir22. 15, 30 ve 40 kuruşa satın aldığı üç evden bahsederek sadece muhtarın evine 700 kuruş ödediğini belirtmektedir. Paşa ile dostane ilişkiler kurduğuna, Fransa'dan gelen çeşitli objelerin bir bölümünü ona vermeyi teklif ettiğine, onu üzebilecek hiçbir şey olmadı̆̆ına değinerek bu nezaketsiz değişimin nedenini tam olarak anlamadı̆̆ını ifade etmektedir. Botta bu problemlerin İstanbul'dan talimatlarla

21 Botta’nın, Fransa Büyükelçiliği’nin gerekli izinleri sağlayacağından şüphesi yoktu. Çalışmalarının yarıda kalmasını ve kesilmesini istemediğinden kazıların sürdürülmesi için gerekli talimatları elde edinceye kadar bekleyecekti.

22 Botta, Khorsabad'da kazı yapabilmesi için höyüğün üzerindeki tüm köyü satın almak zorundaydı. Botta mektubunda iki ay önce köyü satın alabileceğini çünkü kendisine teklif edildiğini belirtmektedir. Köy ve çevresinin bulunduğu arazi bir caminin mülkiyetinde bulunduğu için kanunu ihlal etmeksizin satılamayacağ belirtilmektedir. Burada bulunan evler içinde yaşayan köylülerindi. Fakat köyün inşa edildiği arazi ve çevresi az veya çok bu alandan elde edilen geliri paylaşan bazı bireylere aitti (Buckingham, 1851, s. 61-63). Osmanlı İmparatorluğu'nda toprak mülkiyeti ile ilgili çeşitli nedenlerden dolayı Botta bu evleri satın almaya çalıştı̆̆ında köylülerle, arazinin sahipleri ve vilayetin paşasıyla bir dizi sorunlar yaşamıştır. 
yapıldı̆̆ına inanmamaktadır. Özellikle Paşa'nın, yabancıların bir tanık olarak onun şiddet ve yağma olaylarını ihbar edeceğinden korktuğuna ve endişelendiğine değinmektedir”.

Botta, Bab-1 Ali'nin Paşa'nın tarafını tutması halinde ve çalışmasının yasaklanması durumunda, düşünebileceğinizden çok daha ağır sonuçları olacak diye elçiliği şöyle uyarmaktadir;

"Sizden ricam bütün bu engelleri kaldıracak emirleri Bab-ı Ali'den elde etmek için biraz çaba göstermeniz. Araştırma konum ne yerel otoriteye ne de Türk hükümetine zarar vermiyor. Burada çalışmamın yasaklanması sonuç olarak bir kötü niyet işareti olacaktır ve hatta politik olarak herhangi bir kuşku oluşturmasalar bile isteklerimizin hiçbir şey ifade etmediğini gösterecektir. Ekselanslarının nüfuzuyla çok kötü sonuçlanacak bu durumun önleneceğini umuyorum”, dedikten sonra bugün dünyada benzer barbarlığın sergilenebileceği Musul'dan başka bir yer yoktur diye devam etmektedir ${ }^{23}$.

Botta'nın mektubundan 5 gün sonra 25 Ramazan 1259/19 Ekim 1843 tarihli bir raporda bu konu işlenmektedir. Musul'a 4 saat mesafede Hastaabad köyünde toprak altında kaybolmuş olan bazı eski binalardan bir harabe olduğu, bu harabede taş üzerinde birtakım tasvirlerin bulunduğu ve bu harabenin araştırılarak ortaya çıkarılmaları için konsolos tarafından kazılmasına başlandığı belirtilmektedir. Konsolosun arada gidip yazın şiddetli sicağında oturmak ve amelelerin dinlenmesi için 3 ay boyunca ağaç ve topraktan iki üç dam yapmak istediği ve verilen sürenin bitiminde bu damları yıkacağı konsolos tarafından gerekli otoritelere bildirilmiştir. Mühürlü bir belge teslim etmiş olan konsolosun isteği üzerine izin verilerek tescil olunmuş ise de konsolosun bu köyde köşk gibi yüksek büyük bir bina yaptırdığı ifade edilmektedir. Bu binanın içinde büyük bir eyvan, üç oda, büyük bir avlu ve dört tarafında kırk kadar mazgal delikleri bulunduğundan bahsedilmektedir. Sağlam kap1 ve pencerelerinin tahta ve ağaçtan yapıldığı belirtilmektedir. Kendi mülklerinin kazılması dolayısıyla bazı köylüler damların yapılmasının kendilerine zararı vereceği düşüncesiyle bir dilekçe yazarak bu yerin keşfi için ricada bulunmuşlar. Bu yerin keşfi ve adı geçen binanın araştırılması için bir memur gönderilir. Memur binanın aynı köylülerin dediği şekilde yapıldığını ve bitirilmek üzere olduğunu rapor ederek buraya ait bir parça resmi de raporuna eklemiştir ${ }^{24}$ (Fig. 2). Rapora eklenen bu planda Botta'nın kazı evi, kazdığı alanlar ve köy evleri ve yukarıda bir akarsu ayrıca işlenmiştir. 8 adet köy evi ve bu evlerin çevresinde kazılmış alanlar özellikle plana işlenmiştir. Ancak köy evlerinin yanındaki kazı evi gerçekten de köy evlerine göre oldukça büyük ve mazgal deliklerine sahip kale tipi bir yapı gibi çizilmiştir. Dikdörtgen planlı yapı, büyük bir avlu ile çevresindeki üç oda ve bir tuvaletten oluşmaktadır. Giriş kapısı, Kasr Kapısı olarak adlandırılmıştır. Söz konusu planın mimar ve ressam gibi büyük bir titizlikle çizildiği anlaşılmaktadır. Botta'nın kale gibi çizilen kazı

23 İ.MSM. 68/1987, 2 Zilhicce 1259/24 Aralık 1843.

24 İ.MSM. 68/1987, 2 Zilhicce 1259/24 Aralık 1843. 
evi, köy evleri ve çevresinde kazılan alanlar ayrıca gri ile boyanmıştır. Kazı evinin kapıları ise sarı bir renkle boyanmış olup kapı üzerinde yer alan süsleme çivileri dahi belirtilmiştir. Odalardaki pencereler ise korkuluklarıyla birlikte plana işlenmiştir. Kazı evinin duvarlarında ise mazgal biçimli boşluklar vurgulanmıştır.

Bu konu ile ilgili 29 Ramazan 1259/23 Ekim 1843 tarihli bir diğer raporda ise;

Musul'dan 4 saat mesafede bulunan Hastaabad köyünde toprak altında bulunan harabede kazdıkları su kuyularından üzerinde çeşitli tasvirlerin bulunduğu taşlar çıktığına değinilmektedir. Burada çalışan Fransa konsolosunun bu tasvirli taşları çıkarmak için bundan 5-6 ay önce harabede kazıya başladığı belirtilmektedir. Ancak yazın şiddetinden dolayı amelelerin dinleneceği bir yer yapılmasına izin verildiği halde yapılan bu bina işin bitiminde yıkılacakken bu şekilde topraktan iki üç kulübe yaptırılmasına izin verilmiş ise de konsolosun bu köyde çok büyük bir inşaata başladığ 1 belirtilmektedir. Bu çalışmaların civardaki hanelerden bazılarının temeline zarar verdiği ve yıktığı rapor edilmektedir ${ }^{25}$.

Tüm bu yazışmalar neticesinde Fransa kralı, İstanbul Büyükelçisi Baron de Bourqueney’e gönderdiği 8 Şevval 1259/1 Kasım 1843 tarihli bir takririnde, birkaç ay önce Musul'da tarihte Ninive ismiyle bilinen şehre ait kalıntıların bulunduğuna değinmektedir ve bu konunun Fransa konsolosu tarafindan kendilerine bildirildiğinden bahsetmektedir. Avrupa'da bulunan tarih âlimlerinin söz konusu kalıntıların keşif ve araştııılmasının bilgilerini arttırması ümidiyle sevindiklerine değinmektedir. Musul'da bulunan bu eski ve kadim binaların resim ve planlarını çıkarmak, yazılarını kopyalamak üzere Fransa tarafından Flandin adındaki ressam Musul'da konsolosun yanına tayin edilip gönderilecektir. Adı geçen şehrin kalmış olan binalarını ortaya çıkarmak konusunda kazı yapmak gerekirse konsolos ile ressama gerekli olan iznin verilmesi ve kolaylık gösterilmesini içeren bir emirname verilmesi rica edilmektedir ${ }^{26}$.

8 Şevval 1259/1 Kasım 1843 tarihiyle Fransa Konsolosluğu tarafından baş tercümanına verilen bir talimat bu konuya şöyle değinmektedir; Musul'daki Fransa konsolosu tarafından kazısına başlanmış ve şöhreti bütün Avrupa'da yayılmış bu bilimsel çalışmanın tamamlanmasına Musul valisinin engel çıkardığına değinilmektedir. Musul valisinin aşırı tutumunun büyük bir hatayı ortaya çıkardığına vurgu yapılmaktadır. Osmanlı Devleti'nin durumdan haberdar olduktan sonra bu tutuculuğun kaldırılması konusunda gerekeni yapacağına şüphe edilmese de bu konuda Hariciye Nazırı'nın (Dış İşleri Bakanı Rıfat Paşa) dikkatini çekecek bazı durumlar bildirilmek istenmektedir. "Konsolosun gayreti ile ortaya çıkarılan eski resimli taşlar Asya'nın eski milletlerinin tarihini aydınlatacaktır. Bu haber Paris ve Londra ve Petersburg gibi Avrupa başkentlerinde müjdelenmiştir. Avrupa'daki bilim adamları bu resimli taşların birer birer çıkarılıp getirilmesinde sabırsızlanmaktadırlar. Bir

25 İ.MSM. 68/1987, 2 Zilhicce 1259/24 Aralık 1843.

26 İ.MSM. 68/1987, 2 Zilhicce 1259/24 Aralık 1843. 
memleketin valisi tarafindan bu işin engellenmesi maazallah ĕger bu saydiğım kentlerde yayılırsa valinin ne büyük afetlere yol açacağını hesap eylemeye cesaret edemem. Bu durum Avrupa'dakilerin gazabına da neden olur. Bu talimatın içeriğini Hariciye Nazırı'na anlatmak ve bir suretini de onun eline vermek sizin görevinizdir".

10 Kasım 1843 tarihli ve Fransızca kaleme alınan İstanbul Büyükelçisi Baron de Bourqueney imzalı mektupta da yukarıdaki içerik benzer şekilde yer almaktadır. Hariciye Nazırı Rıfat Paşa'nın bu mesele üzerine dikkati çekilmek istenmektedir. Paris, Londra ve Petersburg'da ve bütün başkentlerde bu tür çalışmaların periyodik yayınların konusu olduğundan ve halkı bilgilendirdiğinden bahsedilmektedir. Botta'nın çalışmalarının önemine ve Avrupa'daki beklentiye değinilerek meselenin çözülmesi beklenmektedir. Özellikle Bourqueney bu gibi engellerin doğuracağı sonuçlardan bahsederken "gerçekten böyle ifadelerin yıkımlarını hesaplamaya cesaret edemiyorum. Buna Osmanlı İmparatorluğu'nun düşmanlarına silah vermek diyorum, Avrupa'da gülünçlük öfke kadar zarar veriyor" 27 diye devam etmektedir. Bourqueney ayrıca yazdıklarının Rıfat Paşa ile paylaşılmasını ve gerekirse bir kopyanın Rıfat Paşa'ya verilmesini talep etmektedir.

Fransa kralı ve konsolosluğunun yazışmaları üzerine Osmanlı Devleti bu konuyu şu şekilde sonlandırmaya çalışmaktadır;

Musul Valisi Mehmed Paşa'dan gelen raporlar değerlendirilerek valinin kazıya ve oraya yapılan binanın inşasına çıkardığı engeller ele alınır. Bu durumun konsolos tarafından büyükelçiliğe yazılarak bildirildiğine değinilir ve bu engelin ortadan kaldırılması istenmektedir. "Bu yerin kazılarak bahsi geçen binaların geçici olarak inşası konusu bazı şartlara ve zamana bağlanmalıdır. Gerekli masraflar taraflarca ödenmek üzere İstanbul'a gelen ressamın yanına bir mübaşir verilerek Musul'a gönderilmesi konsolosluk tarafindan rica olunmuştur. Valinin önce izin verip ardından engel çıkarması uygunsuz bir durumdur. Bu konunun burada sonlandırlarak ressamın yanında mübaşirle beraber gönderilmesi konsolosun tamamen şımarmasına ve valinin de nüfuzunun kırılmasına yol açacaktır. Hiç izin verilmemesi de büyükelçilikten gelen tercüme evraka göre Avrupa'da yankı bulacağından mühendishaneden bir memur tayin edilerek durumun valiye bildirilmesi gerekmektedir. Ressamın gönderilmesi konusunun da Hariciye Nazırı tarafından büyükelçiliğe bildirilmesi önce ruhsat verip ardından engellenmesi uygunsuzdur.

Bu engellemenin tekrarlanması durumunda büyükelçiliğin ısrarı devam edecektir. Masrafi vali tarafindan verilecek bir memurun tayin edilerek kazısına başlanmış olan yerde resim ve antika gibi şeyler bulunduğu halde başka bir yerin kazı ve araştırılmasına ve verilen sürenin uzatılmasına izin verilmemelidir. Kazlya başlanılan müddetin yerinde kaydedilmesi istenmektedir'”28.

27 İ.MSM. 68/1987, 10 Kasım 1843.

28 İ.MSM. 68/1987, 2 Zilhicce 1259/24 Aralık 1843. 
Bütün bu yazışma ve şikâyetler sonucunda Osmanlı Devleti tarafından Fransa konsolosuna verilen 23 Aralık 1843 (23.10 ${ }^{\text {bre }}$.1843) tarihli Fransızca ve Osmanlı Türkçesi’yle ${ }^{29}$ kaleme alınan izin belgesinde kazı süresi ve şartları belirlenerek bu sorun aşağıdaki şekliyle çözülmeye çalışılmıştır ${ }^{30}$.

Fransa tarafından Musul'da bulunan Horsabad köyünde kazısına başlanmış olan yerin çalışmalarının sürdürülmesi için Fransa'dan bu tarafa gelmiş olan ressama ve gerekse Musul'da bulunan Fransa konsolosuna tarafımızdan bazı şartlar ilave edilerek izin verilmiştir ve bu şartlar şunlardır;

1. Kazı yapılan yere yeniden başlayacakları günden itibaren 1 yıl süre verilmiştir. Hiçbir şekilde şikâyet ve tantana çıkmayacak şekilde eğer bu yer bir kimsenin tasarrufunda bulunuyorsa sahibinin razılık gösterip sesini çıkarmamasına bağlıdır. Böylece bu bir yıllık sürenin geçmesi ile işin bitmesinden sonra kazı yapılan yerler tepe ve çukur bırakmayacak biçimde düzeltilecek ve kazı sadece oraya has olup başka bir yere kesinlikle geçilmeyecektir.

2. Ortaya çıkan resimli taşların üzerindeki resim ve yazıların kâğıtlara resmolunması fakat taşımak istedikleri bazı resimli taşlar ve yazıların nakli konusunda mevzu bahis parçaların durumuna göre izin verilmesi gerekir. Bununla birlikte sikke gibi şeyler Devlet-i Aliyye'ye aittir. Ancak bazı eski sikkeler çıktığında numune ve antika olsun diye Fransa'ya götürmek isterlerse bedelini verip her bir şey için izin istemeleri gerekmektedir.

3. Kazı alanında geçici olarak yapılan hanenin lüzumlu olan kısımları bırakılıp iznimizin dışında olan sorunlu yerleri tayin olunan memur tarafından tespit edilerek yıkılmalıdır. Kazı bittikten sonra bu binanın bırakılması için hiçbir şekilde rica edilmemesi ve mukavele gereği derhal yıkılması gerekir. Hiçbir şekilde ek bina yapılmaması, mazgal gibi istihkâmı andıran şeyler görülürse şimdiden imha edilmelidir.

4. Kazı yerinde bazı haneler içinde sahiplerinin izni ve rızası olmadan çukurlar açılmaması, sahipleri rıza gösterirse engel olunmaması, sözleşmenin dışında hiçbir şey yapılmaması ve konsolos tarafindan kazı yapılan bu alanın daha sonra eski sahiplerine birakılması gerekir.

5. Kazısına başlanan yerde şayet resimli taşlar ve antikalar çıkmazsa başka yerlerin kazılmasına ve araştırma yapılmasına ve kazı süresinin uzatılmasına asla izin verilmeyecektir.

29 Osmanlı Devleti'nin ilk çevirmenine göre çevirinin orijinalle uyumlu olduğu ibaresi anlaşmanın Fransızca kısmında ayrıca vurgulanmıştır. Osmanlı Türkçesi ve Fransızca olmak üzere iki dilde hazırlanan bu anlaşmanın her iki tarafında da İstanbul Büyükelçisi Baron de Bourqueney’in imzası bulunmaktadır.

30 Botta kitabında söz konusu fermanı 1843 yılında talep ettiğinden bahsetmektedir. Ancak Flandin'in 4 Mayıs 1844 yılında beraberinde getirdiği bu izin ile ilgili bir tarih vermemektedir (Botta ve Flandin, 1850, s. 10). 
6. Fransa ile devletimiz arasındaki sıcak ilişkilerden dolayı Fransa'nın bizden isteklerine uyarak Musul civarında resimli taşlar ve antika bulunan Horsabad'da bazı yerlerin kazısına izin verilecektir. Musul valisi ile Musul'da bulunan Fransa konsolosu arasında düzenlenip imzalanmak üzere yukarıda beyan edilen bazı şartları içeren senedin içindeki maddeler büyükelçilik tarafindan da uygun görülmüştür. $\mathrm{Bu}$ maddelerin tamamen uygulanması ve aksine dair konsolosunuz tarafından hiçbir şekilde bir teklifte bulunulmayacaktır. Horsabad'da ressam bulundurmak üzere Musul valisi tarafından verilen izne dayanarak geçici olarak inşa edilen hane bu kazı süresinin bitişinde tamamen yıkılacaktır ve dokunulmaması için edilecek hiçbir rica dikkate alınmayacaktır. Bu sözleşmede geçen maddeler konsolosumuz tarafından da uygun görülmüştür. Herhangi bir muhalefet meydana gelirse derhal büyükelçilik kanalıyla men edilecektir. Birçok şartları içeren bu sened, Fransa Devleti elçiliği tarafından yazılıp imzalanarak Devleti Aliyye'ye verildi ${ }^{31}$ (Fig. 3).

Söz konusu izin belgesinin 1. maddesinde geçen "kazı çalışmalarına, yeniden başlayacakları günden itibaren 1 yıl süre verilmiştir" ifadesi bu noktada önemlidir. Ancak Botta kazıya yeniden başladığı dönemi göz önünde bulundurduğumuzda, kazıyı sürdürme iznine sahipken 1844 yılı Ekim ayının sonuna doğru sonlandırmıştır. Böylece çeşitli yazışmaların akabinde ve problemler çözüldükten sonra Khorsabad'daki kazı, Botta ile Mehmed Paşa arasında problemlerin başladığı ve kazının durdurulduğu Ekim 1843 yılından Ekim 1844 yılına kadar olan 1 yıllık süre içerisinde gerçekleştirilmiştir ${ }^{32}$.

Khorsabad kazısı için düzenlenen bu sened 6 maddeden oluşmaktadır ve senedin Osmanlı topraklarında kazı için verilen ilk izin belgesi olduğu söylenebilir. Her ne kadar 1843 yılında ilk ruhsatlı kazının yapıldı̆̆ı belirtilmiş olsa da ayrıntıları bilinmemektedir (Çal, 1997, s. 391; Karaduman, 2004, s. 75).

Khorsabad senedinin 1. maddesi kazı süresini ve bu süre zarfında kazı yapılacak alanın sınırlarını belirlemektedir. Böylece kazı izni sadece ilgili yer bağlamında kullanılacaktır. Senedin 2. maddesinde yer alan resimli taşlar ve bu taşların nakli konusunda taşların durumuna göre iznin gerekliliğinden bahsedilmektedir. Yine bu maddedeki sikkeler ile ilgili düzenlemede sikkelerin devlete ait olduğu ve istenirse izin çerçevesinde bazı eski sikkelerin antika olsun diye bedeli ödenerek Fransa'ya götürülebileceği belirtilmiştir. Bu madde 1869 Asar-1 Atika Nizamnamesi'ndeki 2. ve 4. maddelerin temelini oluşturmaktadır (Çal, 1997, s. 395; Eriş, 2012, s. 35). Özellikle sikke gibi şeylerin devlete ait olduğunun vurgulanması açısından da 1874 ve 1884 Asar-1 Atika Nizamnamelerinin 3. maddesinin temelini oluşturmaktadır. Khorsabad senedinin 3. maddesinde kazı evi olarak inşa edilen

31 İ.MSM. 68/1987, 2 Zilhicce 1259/24 Aralık 1843.

32 Böylece Botta, Khorsabad'da Russell'in belirttiği gibi 1842-1844 yılları arasında değil (Russell, 2017, s. 485) 1843-1844 yıllarında çalışmıştır. 
yapının şikâyete bağlı olarak belirtilen kısımlarının ortadan kaldırılması ve kazı evi ile ilgili düzenlemeleri belirtmektedir. 4. madde kazılacak alanların mülk sahipleri ile ilgili anlaşmaları içermektedir. 5. madde kazılan yerde eser çıkmadığı takdirde başka alanların kazılmasını ve kazı süresinin uzatılmasını engellemektedir. 6. madde ise senedin genel içeriğinden ve taraflar arasındaki bağlayıcılığından bahsetmektedir. Özellikle senedin uygulanması çerçevesinde masrafı vali tarafından verilecek bir memurun da tayin edilmiş olması önemlidir.

Botta'nın Khorsabad kazısı sırasında özellikle Musul valisi ile yaşadığı problemler ve bu problemlerin çeşitli yazışma ve tartışmalar neticesinde Osmanlı Devleti ile Fransa arasında Khorsabad kazısı için düzenlenen ve 6 maddeden oluşan yukarıda ele aldığımız sened bağlamında çözülmesi ve bu verilerin incelenmesi, Osmanlı arkeoloji tarihinin anlaşılması açısından son derece önemlidir. Özellikle Botta’nın Khorsabad kazısı için almış olduğu izin belgesi ve içeriği ile birlikte yine bu dönem ve sonrasında Austen Henry Layard'ın Nimrud ve Van civarındaki çalışmaları ve bulunan eserlerin durumu (Genç, 2018, s. 113-119), Botta'dan sonra Victor Place'nin Khorsabad'daki çalışmaları ve çeşitli uyarılara rağmen bulunan eserlerin taşınma sırasında önemli bir bölümünün Dicle Nehri’nde batması (Genç, 2021, s. 759-774) ve Botta'nın Khorsabad kazısından yaklaşık 20 yıl sonra 1863'ten itibaren John Turtle Wood'un Efes kazısı ve kazı boyunca yaşanan çeşitli problemler ile bu bağlamda Aydın Valisi Hekimbaşı İsmail Paşa’nın itirazları ve önerileri de (Eldem, 2011, s. 312-321) 1869 tarihli nizamnamenin ayak seslerinin önemli bir bölümünü oluşturmaktadırlar. Osmanlı arkeolojisinin gelişim sancılarının anlaşılması da erken dönemdeki bu kazılar ve sonuçlarının ayrıntılarının anlaşılmasıyla mümkündür.

\section{Sonuç}

Botta'nın Khorsabad'da gerçekleştirdiği kazı, inşa ettiği kazı evi ve kazı izni ile ilgili yukarıda verdiğimiz belgeler kazıya başlama aşamasından itibaren Botta'nın yaşadığı güçlükleri ayrıntılı olarak gözler önüne sermektedir. Her ne kadar Botta’nın kazı izni olmadığı belirtilse de (Larsen, 1996, s. 28; Bahrani, 2011, s. 132, 141), bu çalışmada ayrıntılı olarak ele aldığımız raporlar ve mektuplar ile iki ülke arasında imzalanan kazının süresi, yeri, durumu ve şartları ile ilgili anlaşma (Fig. 3), Botta’nın izninin olduğunu açıkca ortaya koymaktadır. Keza köylüler de şikayet dilekçelerinde Botta'nın köyün hizasında bulunan tepeyi kazmak için izin istediğini ve bu izni Paşa'dan aldığını ifade etmektedirler. Musul Valisi Mehmed Paşa'dan alınan izinlerle çalışmasına devam eden Botta 20 Nisan 1843 tarihinde Khorsabad' da inşa edeceği kazı evi için ayrıca izin istemiştir. 21 Ağustos 1843 tarihinde satın aldığı evleri kazı sonrasında sahiplerine geri vereceğini de dilekçesinde isimleri verilen köylülerin şahitliğinde belirtmektedir.

Ancak kazı başladıktan ve kazı evi inşa edildikten bir süre sonra köylüler bu durumdan şikayetçi olmaya başlarlar. Khorsabad'lılar şikayet dilekçelerinde Botta'nın kazılarından bahsederek inşa edilen kazı evindeki avlunun 64 metreden büyük olduğunu, odalarının 
tahkimatlı ve sağlam olduğunu belirtirler. Kazıdan dolayı zarar gördüklerinden bahsederek bu alanda bir keşif yapılmasını isterler. Keşif heyeti gönderilir, kadı'nın raporları ve evin planı çıkarılır. Buna karşın Botta'da 14 Ekim 1843 yılında Fransa Büyükelçisi Baron de Bourqueney'e mektup yazarak problemlerini, yaşadığı sıkıntıları ve nedenlerini sıralar. Paşa'nın kazı evini kale gibi göstermek isteyişinden, kendisine çıkardığı zorluklardan ayrıntılı olarak bahseder ve evin ölçülerini (yaklaşık olarak 21x15 m) verir. Duvarların yüksekliği ise 2 metreye yakındır. 19 Ekim 1843 ve 23 Ekim 1843 tarihli raporlarda konsolosun çok büyük bir inşaata başladığı, köşk gibi yüksek büyük bir bina yaptırdığı ve binanın içinde büyük bir eyvan, üç oda, büyük bir avlu ve dört tarafında kırk kadar mazgal delikleri bulunduğundan bahsedilmektedir. Bu çalışmaların civardaki hanelerden bazılarının temeline zarar verdiği ve yıktığı da belirtilmektedir. Bu alanın keşfi için gönderilen memur binanın aynı köylülerin dediği şekilde yapıldığını rapor ederek, kazılan alanlar, köy evleri ve kazı evinin ayrıntılı bir planını da ekler (Fig. 2). Osmanlı Arşivi'nde bulduğumuz bu planda söz konusu ayrıntılar işlenmiştir. Plana göre üç oda, bir tuvalet ve bir avludan oluşan evin dış duvarlarında kırka yakın mazgal bulunmaktadır. Odaların kapı ve pencereleri, avluya giriş kapısı net olarak belirtilmiştir. Özellikle mazgalların işlenmesi de bir savunma yapısı olduğu algısını pekiştirmeye yöneliktir. Avlunun 64 metreden fazla olduğunun vurgulanması da benzer algıyla ilgilidir. Ayrıca Khorsabad'daki bazı evlerin şematik planı ve Botta'nın kazdığı alanlarda bu plana işlenmiştir (Fig. 2). Bir kale veya savunma yapısı gibi çizilen bu plan aslında Mezopotamya'daki ve arkeoloji literatüründeki ilk kazı evi olma özelliğini taşımaktadır. Botta'nın antik eserlerin parçalarını bir araya getirme, birleştirme ve taşınma sürecinde eserleri çeşitli tehlikelerden koruma amacıyla bu evi inşa ettiğini belirtmesi bu tanımlamayı doğrulamaktadır.

1 Kasım 1843 tarihli bir raporda ise Fransa, Botta'nın Khorsabad'da kazı yapması için Osmanlı Devleti’nden izin istemektedir. Özellikle Musul valisinin çıkardığı engellerin Paris, Londra ve Petersburg gibi Avrupa başkentlerinde duyulması halinde daha büyük problemlerin olacağından bahsederek Hariciye Nezareti’ne gözdağı vermektedir. Bunu üzerine Osmanlı Devleti bu konuyu çözmeye başlamıştır. Musul valisinin önce izin verip ardından engel çıkarması uygunsuz bir durum olarak değerlendirilmektedir. İki ülke arasında krize neden olan kazı şartları ve kazı evinin durumu yeniden gözden geçirilerek gerekli izin Botta’ya verilmiştir. Özellikle masrafı vali tarafından verilecek bir memurun tayin edilmesi, kazısına başlanmış olan yerde resim ve antika gibi şeyler bulunduğu halde başka bir yerin kazı ve araştırılmasına ve verilen sürenin uzatılmasına izin verilmemesi vurgulanmaktadır. Osmanlı Devleti ve Fransa arasında düzenlenen anlaşma ile kazı süresi ve şartları belirlenmiş ve bu sorun çözülmüştür. Khorsabad ile ilgili 6 maddeden oluşan bu kazı ruhsatı veya senedin 1869, 1874, 1884 yıllarında yürürlüğe konulan Asar-1 Atika Nizamnameleri’nin de esin kaynağı olduğu düşünülebilir. 
Fransa Büyükelçisi Baron de Bourqueney’nin çabaları sayesinde özel bir anlaşmayla bu sorun çözüldükten sonra Botta çalışmalarına kaldığı yerden devam etti. Flandin ise önemli ölçüde gecikti ve yaklaşık olarak 4 Mayıs 1844 yılına kadar Musul'a ulaşamadı (Botta ve Flandin, 1850, s. 10). Birçok tartışmaya neden olan Botta'nın kazı evinin ise çalışma bitene kadar kalmasına izin verildi. Flandin'in beraberinde getirdiği 1 yıllık izinle kazılar hemen tekrar başlatıldı. Böylece yaklaşık 6 ay boyunca üç yüz işçiyle Botta 1844 yılı Mayıs ayının ortalarından 1844 yılı Ekim ayının sonuna kadar çalışmalarını sürdürdü (Botta ve Flandin, 1850, s. 12). Ağustos ayında Botta, Layard'a elde ettikleri başarılardan ve Flandin'in becerilerinden söz eden bir mektup yazdı. Flandin ve Botta birlikte iyi çalışıyorlardı, kabartmalar ortaya çıktıkça Flandin büyük bir özenle çizimlerini yapıyor ve yapıların planını çıkarıyordu. Botta ve Flandin tarafından dönemin standartlarına göre kalabalık işçi grupları ve aceleyle sürdürülen kazılarla sarayın tamamı değilse de büyük bölümü ortaya çıkarılmıştır. Dış kente hemen hemen hiç dokunulmamıştır. Botta 14 büyük salon ve bazı dış cephelerle birlikte yapıların kuzey bölümünü kazmıştır (Buckingham, 1851, s. 58-65; Hilprecht, 1903, s. 78-79; Larsen, 1996, s. 29).

Botta 1844 yılının Ekim ayında Khorsabad'daki kazı çalışmalarını sonlandırdı. Khorsabad gemi geçişine uygun nehirlerden uzak bir mesafede yer alıyordu; çok ağır ve büyük taş bloklar, 25 km. uzaktaki Musul'a taşınmak zorundaydı. Assur kabartma ve heykellerinin Fransa'ya sevkiyatı büyük güçlüklerle gerçekleştiriliyordu. Köylüler tarafından salların bulunduğu alana taşınan bu devasa eserler burada sallara yüklenerek Dicle Nehri'nden Basra Körfezi'ne ulaşıyordu ve buradan Fransa'ya gönderiliyordu. Botta Assur'lu mimarların kullandığı taşıma yöntemlerini kullandı. Kabartmaların Musul'a taşınması için büyük yük arabaları yaptırdı. Bu yük arabalarını çeken bazı öküzleri Mehmed Paşa kullanmaları için onlara vermişti fakat sonra hemen geri aldı. Yağmurlu mevsimde bu taşıma gerçekleştirildiğinden tekerlekler çamura batıyordu. Bu nedenle Khorsabad ve Musul arasındaki yolda bu boğalardan birini bırakmak zorunda kaldı. Bütün eserlerin nehir kenarına taşınma işlemi Haziran 1845 yılına kadar sürdü. Yük arabaları Musul'a vardıktan sonra heykeller, yüzlerce şişirilmiş koyun derisiyle oluşturulan büyük sallara/keleklere yüklenerek önce Bağdad'a ve ardından Basra Körfezi'ne doğru yola çıktı. Basra'dan bir Fransız gemisine yüklenerek Le Havre'ye ulaşan bu eserler buradan da Paris'e gönderilmek üzere yola çıkarıldı. Şubat 1847 'de bu eserler Paris'e ulaştı. Botta'nın Khorsabad'da kazılara başlamasından tam olarak dört yıl sonra 1 Mayıs 1847 yılında ilk Assur eserlerinden oluşan koleksiyon Louvre'de ziyarete açıldı (Buckingham, 1851, s. 67-69; Hilprecht, 1903, s. 79-80; Larsen, 1996, s. 32). Botta kazdığ yerleşimin Ninive olduğunu zannederek 1849 ve 1850 yıllarında ise Khorsabad kazısını ve ayrıntılarını Flandin ile birlikte "Monument de Ninive" başlığı altında yayınlandı (Botta ve Flandin, 1849; Botta ve Flandin, 1850). 
Hakem Değerlendirmesi: Dış bağımsız.

Çıkar Çatışması: Yazar çıkar çatışması bildirmemiştir.

Finansal Destek: Yazar bu çalışma için finansal destek almadığını beyan etmiştir.

Peer-review: Externally peer-reviewed.

Conflict of Interest: The author has no conflict of interest to declare.

Grant Support: The author declared that this study has received no financial support.

\section{Kaynakça/References}

İ.MSM : İrade Mesail-i Mühimme

Bahrani, Z. (2011). Mezopotamya'nın Keşfinin Anlatılmamış Hikayesi. Geçmişe Hücum: Osmanlı İmparatorluğu'nda Arkeolojinin Öyküsü 1753-1914. Z. Bahrani, Z. Çelik ve E. Eldem. (Ed), (s. 125155). İstanbul: Salt/Garanti Kültür A.Ş.

Bonomi, J. (1857). Nineveh and Its Palaces: The Discoveries of Botta and Layard, Applied to the Elucidation of Holy Writ. London: H. G. Bohn.

Botta, P. É., \& Flandin E. N. (1849). Monument de Ninive: découvert et décrit par M.P.E. Botta; mesuré et dessiné par M.E. Flandin. Paris: Imprimerie Nationale.

Botta, P. É., \& Flandin E. N. (1850). Monument de Ninive: découvert et décrit par M.P.E. Botta; mesuré et dessiné par M.E. Flandin. Paris: Imprimerie Nationale.

Buckingham, J. S. (1851). The buried city of the East, Nineveh: a narrative of the discoveries of Mr. Layard and M. Botta at Nimroud and Khorsabad; with descriptions of the exhumed sculptures, and particulars of the early history of the ancient Ninevite kingdom. London: Office of the National Illustrated Library.

Bunnens, G. (1996). Syro-Anatolian influence on Neo-Assyrian town planning. Cultural Interactions in the Ancient Near East: Papers Read at a Symposium Held at the University of Melbourne, Department of Classics and Archaeology (29-30 September 1994). G. Bunnens (Ed), (s. 113-128). Louvain: Peeters.

Çal, H. (1997). Osmanlı Devletinde Asar-1 Atika Nizamnameleri. Vakıflar Dergisi, Ankara 26, 391-400.

Eldem, E. (2011). Huzurlu Bir İlgisizlikten Sıkıntılı Bir Kaygıya: Osmanlıların Gözünde Eski Eserler, 17991869. Geçmişe Hücum: Osmanlı İmparatorluğu'nda Arkeolojinin Öyküsü 1753-1914. Z. Bahrani, Z. Çelik ve E. Eldem (Ed). (s. 281-329), İstanbul: Salt/Garanti Kültür A.Ş.

Eriş, M. Ü. (2012). Asar-1 Atika Nizamnamelerinden 2863 Sayılı Kültür ve Tabiat Varlıklarını Koruma Kanununa Mevzuatın Karşılaştırmalı Bir İncelemesi Kültür ve Turizm Bakanlığı Kültür Varlıkları ve Müzeler Genel Müdürlüğ̈̈. Ankara.

Fuchs, A. (1994). Die Inschriften Sargons II. aus Khorsabad Göttingen: Cuvillier.

Gates, C. (2011). Ancient Cities. The Archaeology of Urban Life in the Ancient Near East and Egypt, Greece, and Rome. Abingdon, Oxon; New York, Routledge.

Genç, B. (2018). Archaeology of Destruction: Toprakkale. Iraq, 80, 113-137.

Genç, B. (2019). First Steps in the Archaeology of Assyria: Botta's Letters and the "Excavation House" at Khorsabad. Iraq, 81, 145-171.

Genç, B. (2021). Memory of destroyed Khorsabad, Victor Place, and the story of a shipwreck. Journal of the Royal Asiatic Society, 31(4), 759-774.

Hilprecht, H. V. (1903). Explorations in Bible Lands: During the 19th Century. Philadelphia: A. J. Homan and Company. 
Karaduman, H. (2004). Belgelerle İlk Türk Asar-1 Atika Nizamnamesi. Belgeler, XXV(29), 73-92.

Kuneralp, S. (2003). Son Dönem Osmanlı Erkân ve Ricali (1839-1922). Prosopoprafik Rehber. (2 bs). Istanbul: Isis.

Larsen, M. T. (1996). The Conquest of Assyria: Excavations in an Antique Land, 1840-1860. London: Routledge.

Livingstone, A. (1989). Court Poetry and Literary Miscellanea. Helsinki - Finland: Helsinki University Press.

Loud, G. \& Altman C. B. (1938). Khorsabad, Part II: The Citadel and the Town. Chicago: The University of Chicago.

Loud, G., et al. (1936). Khorsabad, Part I: Excavations in the palace and at a city gate. Chicago: The University of Chicago.

McGovern, F. H. \& McGovern J. N. (1986). "BA” Portrait: Paul Émile Botta. The Biblical Archaeologist, 49(2), 109-113.

Mohl, J. (1843). Lettres de M. Botta. Journal Asiatique, II(7): 61-72.

Mohl, J. (1845). Lettres de M. Botta sur ses découvertes a Khorsabad, pres de Ninive. Paris: Imprimerie royale.

Niebuhr, C. (1778). Reisebeschreibung nach Arabien und den umliegenden Ländern. Kopenhagen: Nicolaus Möller.

Rich, C. J. (1836). Narrative of a Residence in Koordistan, and on the Site of Ancient Nineveh, Vol. I. London: James Duncan.

Rich, C. J. (1836 ). Narrative of a Residence in Koordistan, and on the Site of Ancient Nineveh, Vol. II. London, James Duncan.

Russell, J. M. (2017). Assyrian Art. A companion to Assyria. E. Frahm (Ed). (s. 453-510). Hoboken, NJ, John Wiley \& Sons:

Tadmor, H., et al. (1989). The Sin of Sargon and Sennacherib's Last Will. State Archives of Assyria Bulletin, 3(I), 3-51.

Thompson, R. C. (1934). The Buildings on Quyunjiq, the Larger Mound of Nineveh. Iraq, 1(1), 95-104.

Turner, G. (1970). Tell Nebi Yūnus: The ekal māšarti of Nineveh. Iraq, 32(1), 68-85. 


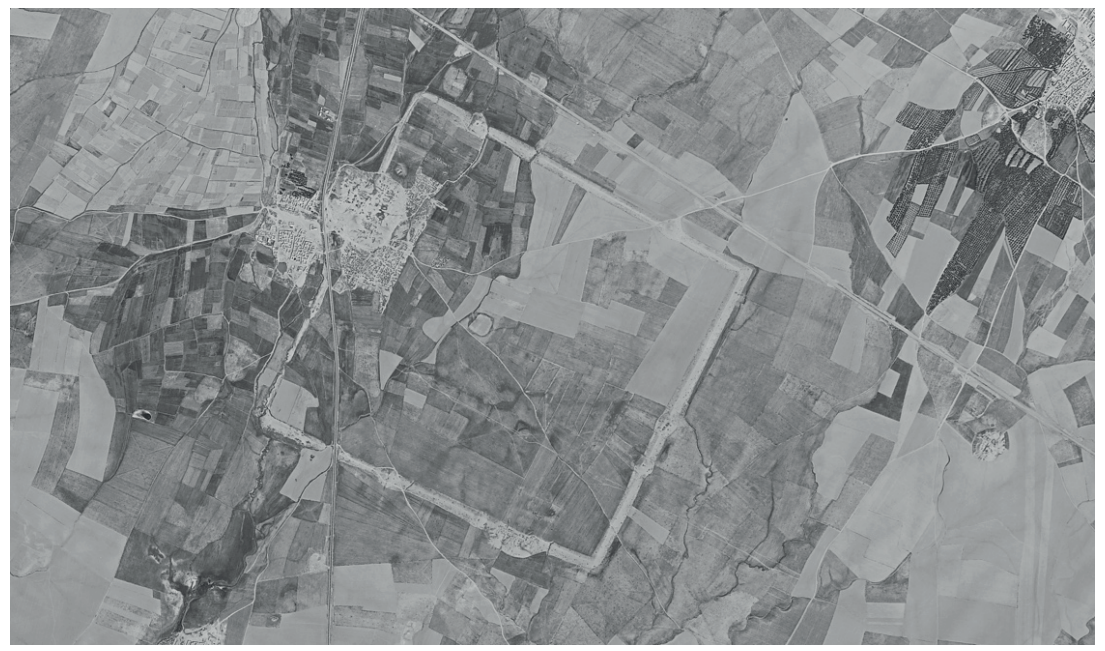

Figür 1. Khorsabad'ın havadan görünümü ve planı (Photo J. Macginnis)

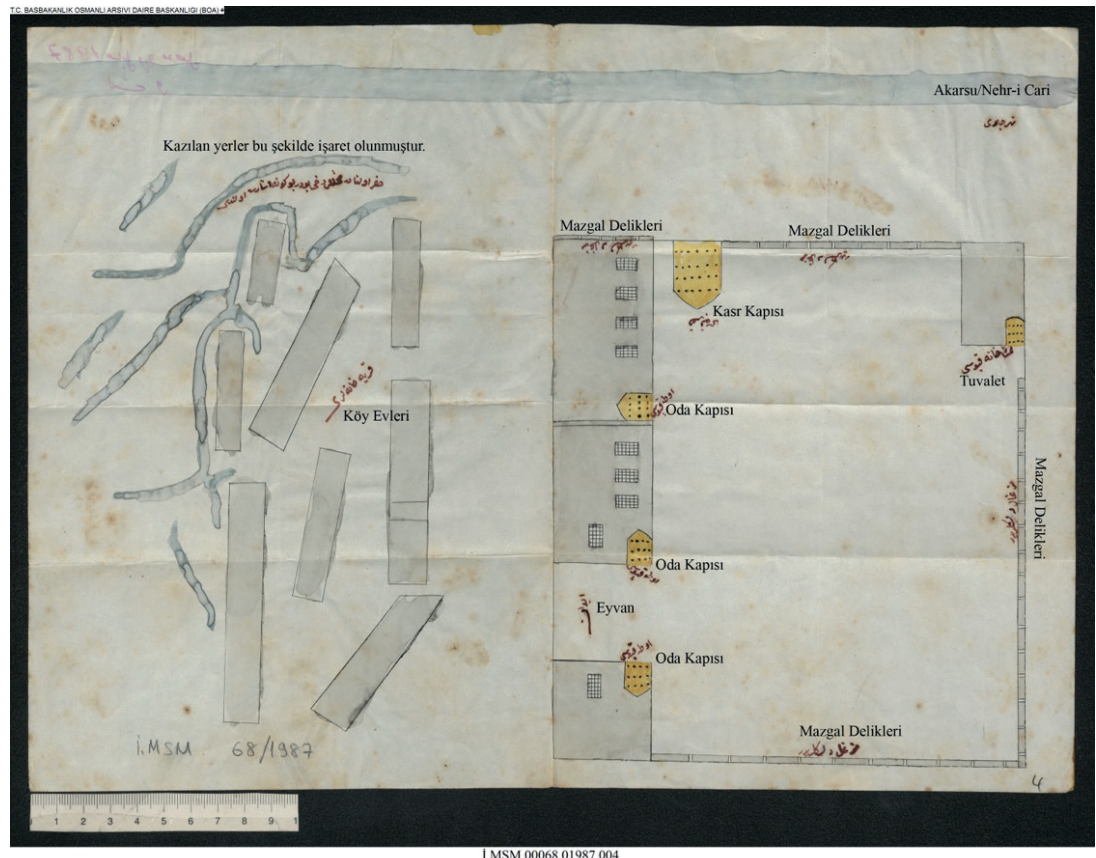

Figür 2. Botta'nın Khorsabad'da yaptırdığı kazı evinin Mehmed Paşa tarafından çizdirilen planı 


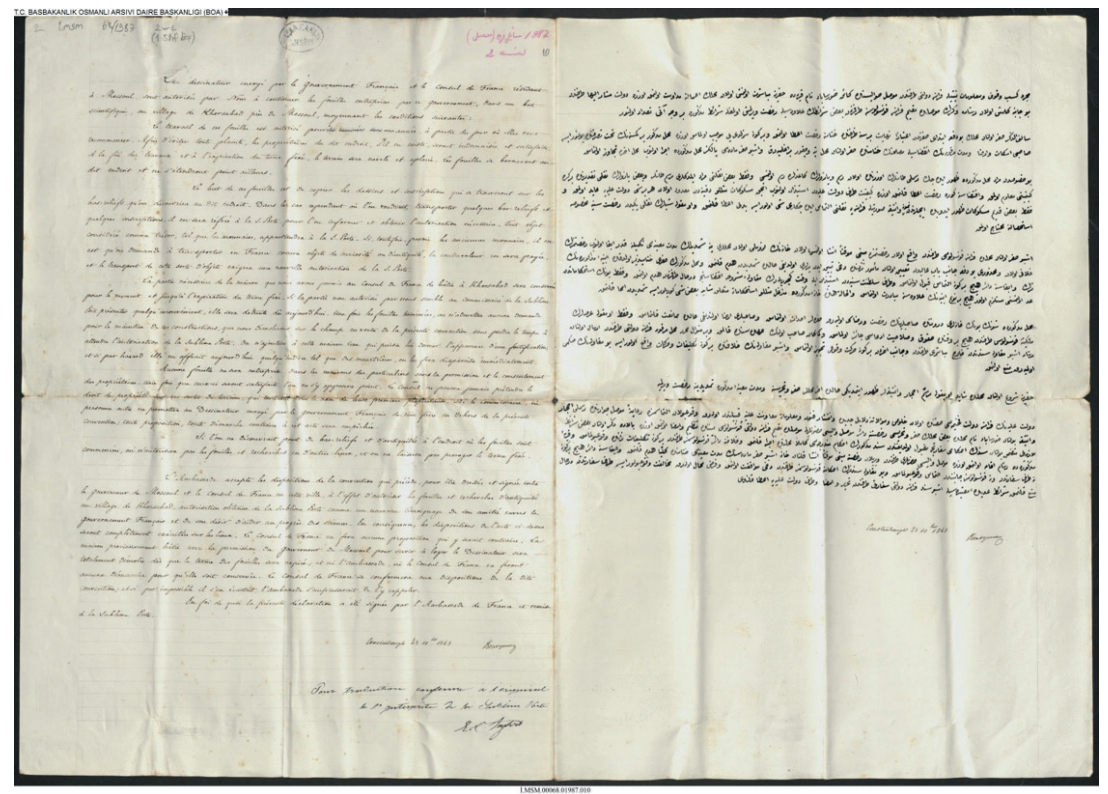

Figür 3. Osmanlı Devleti tarafından Fransa konsolosuna verilen ilk kazı izin belgesi 
